Relations industrielles

Industrial Relations

\title{
SERVICE D'EDUCATION DE LA C.T.C.C, Syndicat, instrument de libération des travailleurs, a 30-page booklet, Quebec, 1951.
}

Volume 7, numéro 1-2, décembre 1951, mars 1952

URI : https://id.erudit.org/iderudit/1023128ar

DOI : https://doi.org/10.7202/1023128ar

Aller au sommaire du numéro

Éditeur(s)

Département des relations industrielles de l’Université Laval

\section{ISSN}

0034-379X (imprimé)

1703-8138 (numérique)

Découvrir la revue

Citer ce compte rendu

(1951). Compte rendu de [SERVICE D'EDUCATION DE LA C.T.C.C, Syndicat, instrument de libération des travailleurs, a 30-page booklet, Quebec, 1951.]

Relations industrielles / Industrial Relations, 7(1-2), 135-135.

https://doi.org/10.7202/1023128ar

Tous droits réservés @ Département des relations industrielles de l’Université Laval, 1952
Ce document est protégé par la loi sur le droit d'auteur. L'utilisation des services d'Érudit (y compris la reproduction) est assujettie à sa politique d'utilisation que vous pouvez consulter en ligne.

https://apropos.erudit.org/fr/usagers/politique-dutilisation/ 
Alfred Charpentier, Montée Triomphale de la CTCC, a 123-page volume, Montreal, 1951. For sale by the author, 7080 Hutchison Street, Montreal.

The former president of the Canadian and Catholic Confederation of Labour does not attempt to write a complete history of this movement but rather a chronology of the important events which have marked its development. This book is an excellent synthesis to initiate anyone who wishes to have an idea of Catholic syndicalism here.

SERvice D'Education DE LA C.T.C.C., Syndicat, instrument de libération des travailleurs, a 30-page booklet, Quebec, 1951 .

Booklet for workers, explaining the necessity, the nature, the part and the working of a union as well as the organization and function of the Canadian and Catholic Confederation of Labour.

Service d'Educhtion De r.A C.T.C.C., Pour bien diriger un syndicat, Service d'education du Conseil General des Syndicats Catholiques de Quebec, 1950, a 76-page booklet.

Booklet for union officials contains what should be known to run a union in a democratic way: meeting procedure, filing system, union accounting. Especially written for labour unions, but may be used by any kind of group.

Readings in Labour Economics: edited by Francis S. Doody, Associate Professor of Economics, Boston University, College of Business Administration, 1950, Addison-Wesley Press, Inc., Cambridge, 42, Mass.

The Editor, Francis S. Doody, has tried in this volume to add a complement to the courses given in the field of labour, by re-publishing oustanding articles chosen from economic papers and reviews. These articles show the recent tendency to accentuate the economic aspect of labour rather than labour problems and the tendency to increase more and more the importance of collective agreements in the field of labour relations. The subjec:s covered are the organization of unions, salary policies, the nature and extension of cullective agreements, the application of programmes of social security and the economic aspects of the labour laws. The positive aspect is also considered in articles, accompanied with practices and policies used in labour relations.

John W. McConnell and Robert F. Risley, Economic Security: A Study of Community Needs and Resources, 79 pages, New York State School of Industrial and Labor Relations, Cornell University, Bulletin No. 18, Ithaca, N.Y., 1951. 25 cents each for orders of more than five copies.

John W. McConnell is a professor at the New York State School of Industrial and Labor Relations and Robert F. Risley is administrative assistant to the Dean of the New York State School of Industrial and Lahor Relations.

The authors analyze, in taking into account the economic circumstances, the concept that the residents of Elmira, city situated in Chemung County, New York, have of their need for economic security. They study the various sources of security that is, private or public, put at their disposition by private enterprises of the place or by the community itself, and examine the attitudes of these citizens in regard to these various institutions and to the programmes of social security put into operation by them.

For such a widespread survey, a three-pronged approach was made which was presented at the beginning of the book.

1. The chief income producers of a selected sample of Elmira dwelling units were interviewed to determine from their point of view the extent of the protection from economic distress available to them and to determine their knowledge and attitudes concerning social security programmes. 